\title{
Contribution of Organically Grown Crops to Human Health
}

\author{
Eva Johansson ${ }^{1 *}$, Abrar Hussain ${ }^{2}$, Ramune Kuktaite ${ }^{1}$, Staffan C. Andersson ${ }^{1}$ and \\ Marie E. Olsson ${ }^{1}$
}

1 Department of Plant Breeding, The Swedish University of Agricultural Sciences, P.O. Box 101, Alnarp, SE 23053, Sweden; E-Mails: Ramune.kuktaite@slu.se (R.K.);

Staffan.andersson@slu.se (S.C.A.); Marie.olsson@slu.se (M.E.O.)

2

Department of Biosciences, COMSATS Institute of InformationTechnology, Sahiwal Campus,

Comsats Road, Sahiwal 57000, Pakistan; E-Mail: Abrar.hussain@ciitsahiwal.edu.pk

* Author to whom correspondence should be addressed; E-Mail: Eva.johansson@slu.se;

Tel.: +46-40-415-562; Fax: +46-40-415-519.

Received: 30 January 2014; in revised form: 27 March 2014 / Accepted: 28 March 2014 /

Published: 8 April 2014

\begin{abstract}
An increasing interest in organic agriculture for food production is seen throughout the world and one key reason for this interest is the assumption that organic food consumption is beneficial to public health. The present paper focuses on the background of organic agriculture, important public health related compounds from crop food and variations in the amount of health related compounds in crops. In addition, influence of organic farming on health related compounds, on pesticide residues and heavy metals in crops, and relations between organic food and health biomarkers as well as in vitro studies are also the focus of the present paper. Nutritionally beneficial compounds of highest relevance for public health were micronutrients, especially $\mathrm{Fe}$ and $\mathrm{Zn}$, and bioactive compounds such as carotenoids (including pro-vitamin A compounds), tocopherols (including vitamin E) and phenolic compounds. Extremely large variations in the contents of these compounds were seen, depending on genotype, climate, environment, farming conditions, harvest time, and part of the crop. Highest amounts seen were related to the choice of genotype and were also increased by genetic modification of the crop. Organic cultivation did not influence the content of most of the nutritional beneficial compounds, except the phenolic compounds that were increased with the amounts of pathogens. However, higher amounts of pesticide residues and in many cases also of heavy metals were seen in the conventionally produced crops compared to the organic ones.
\end{abstract}


Animal studies as well as in vitro studies showed a clear indication of a beneficial effect of organic food/extracts as compared to conventional ones. Thus, consumption of organic food seems to be positive from a public health point of view, although the reasons are unclear, and synergistic effects between various constituents within the food are likely.

Keywords: organic farming; micronutrients; bioactive compounds; in vitro; pesticide residues; animal studies

\section{Introduction-Organic Agriculture Today and in the Future}

Organic agriculture is defined today in various ways, although some common principles exist — to not use synthetic fertilizers and chemical pesticides [1]. Some commonly used definitions of organic agriculture are the ones used by FAO_- "Organic farming is a holistic production management system which promotes and enhances agro-ecosystem health, including biodiversity, biological cycles, and soil biological activity" [2], IFOAM - "Organic agriculture is a production system that sustains the health of soils ecosystems and people" [3], and USDA- "Organic farming is a production system that excludes the use of synthetically produced fertilizers, biocides, growth regulators, and livestock feed additives such as antibiotics and growth hormones" [4]. Thus, besides the fact that no synthetic fertilizers and chemical pesticides are used in organic farming, there is a general idea that organic farming contributes to improved human and environmental health.

The possibly positive impact on human health as well as on environment is, together with increasing consumer demand, the key reasons why a number of governments have set goals as to how much organic agriculture should increase in their respective countries. Some examples of food policies related to development of organic production are: (i) the Food, Conservation and Energy Act of 2008 in the USA, with a mandatory five-fold funding increase for organic research programs and cost-share assistance for farmers and handlers [5], and (ii) The European Action Plan for Organic farming from 2004, focusing on strengthening information and research as well as improving production standards and streamlining public support [6]. In Africa, the African Union has taken a decision to support and develop frameworks and strategies for organic policies [7].

The mentioned food policies, together with economic subsidies and increased income opportunities for the farmers are part of the explanation for the rapid development of organic agriculture, which is nowadays practiced in more than 160 countries [7]. A total of 37 million hectares of land were grown organically in 2010, which is more than a three-fold increase during the last 10 years, involving 1.6 million producers, although still only $0.9 \%$ of the agricultural land is grown organically [7]. From 2009 to 2010, there has for the first time during the last 10 years been a small decrease in the world organic production. However, large increases are still seen in most of the European countries in terms both of increase of agricultural land for organic production, organic market size and per capita consumption [7]. However, as to organic producers, more than $80 \%$ are found in the developing countries, where the largest share of emerging markets are also present [7]. Still, the main part of the organically produced products in developing countries is exported to developed countries and the main importers of such products are the United States, Germany and France [7]. Due to the fact that we still 
see an ongoing and steady increase in organic market and production in Europe as well as emerging economies and markets in the developing world, one might expect a continuous increase in the market share of organic products as well as in area of organically certified land around the world for organic production.

Quite a number of studies are available examining the impact on amounts of certain nutritional compounds of organic crop cultivation practices (e.g., [8-10]). However, only a few studies (e.g., [11]) have focused on a more holistic and full understanding as to whether organic production influences public health.

Thus, the aim of the present article is to review and compile results and draw conclusions related to the influence of organic agriculture and crops grown therein on public health. Thereby, conclusions related to food factors influencing public health, nutritional compounds in crops and relations to daily intake as well as significance of organic cultivation on amounts of nutritional compounds are emphasized. Finally, the impact of organic food on public health will be emphasized based on animal, human and in vitro studies.

\section{Important Factors for Public Health-Impact of Nutritional Compounds from Crops}

Public health has to a large extent been coupled to lifestyle patterns including dietary changes and selection of daily food [12]. An increasing problem in both developing and developed countries is the commonly reported change in intake patterns resulting in chronic non-communicable diseases (NCDs - non-infectious or transmissible type of diseases), including obesity, cardiovascular diseases, stroke, diabetes etc. [12]. Similarly as the intake of sugar and non-essential fats are increasing with the changing lifestyle, nutrient sufficiency in the daily food is decreasing [12]. For a productive life and longevity, sufficient intake of nutrients is essential. Both in the developing and developed world, malnourishment in terms of micronutrients is a large problem, and over three billion people are expected to suffer from such malnourishment [13-15]. Thus, besides the diseases mentioned above, resulting from a sedentary life-style with a too high intake of sugar and fat, micronutrient deficiency in the food also contributes to lower productivity, learning disabilities and increased mortality rates [15].

An increased number of recent studies have shown the positive impact of consumption of crop-based foods on human health $[13,14,16]$. Especially intake of fruits and vegetables has been found important to prevent cardiovascular diseases and obesity [14,16]. Beside fruits, berries and vegetables, other crop-based foods such as e.g., cereals and legumes are also beneficial for human health $[17,18]$. Several reasons can account for the impact on human health. Firstly, crop-based food is generally low in sugar and fat, especially processed versions, but these food products are also rich in nutritionally beneficial components, e.g., micronutrients and antioxidants or bioactive compounds [14].

Worldwide, nutritional deficiency is known to cause two thirds of all childhood deaths. The main problems in such nutritional deficiency are primarily a too low intake of vitamin A (some carotenoids), iron, and zinc [13-15]. However, also other micronutrients such as selenium and iodine are known to be of importance in nutrient deficiency [14], as are other vitamins and bioactive compounds, such as for example vitamin E (tocochromanols) and phenolic compounds [19,20]. Besides causing childhood deaths, deficiency in the mentioned compounds is supposed to contribute to 
an increased amount of NCDs [21]. Thus, relationships between contents of the mentioned compounds in various crops, influences of organic farming, and relations to public health will be discussed below.

\section{Content of Compounds in Various Crops Compared to Daily Intake}

The recommended daily intakes of various micronutrients differ depending on the specific compound, with high amounts for e.g., calcium (1,000 mg/day), sulphur (850-1,500 mg/day), potassium (3,500 mg/day), and low amounts for e.g., selenium (0.03-0.07 mg/day) and molybdenum $(0.05-0.10 \mathrm{mg} /$ day $)$. For the most commonly deficient micronutrients, the recommended daily intake is $0.6 \mathrm{mg} /$ day for vitamin $\mathrm{A}, 10 \mathrm{mg} /$ day for iron and $10 \mathrm{mg}$ /day for zinc [22,23]. Recommended daily intake for vitamin $\mathrm{E}$ is $10 \mathrm{mg} /$ day [22] and for phenols it is $500 \mathrm{mg} /$ day [24].

Recommended daily intake of micronutrients, antioxidants and bioactive compounds can be reached through a proper mixture of suitable food, through intake of multivitamin and/or multimineral pills or through fortification of the food. Recent studies have indicated benefits of natural intake of food with sufficient levels of micronutrients instead of compensation with supplements or pills [25]. Results on smokers even showed an adverse effect on cancer patients with intake of $\beta$-carotene and retinol supplementation [26]. Studies on whether fortification of food contributes similarly to health as natural intake of micronutrients, antioxidants and bioactive compounds has been limitedly investigated. To conclude, intake of plant-based food has been shown to contribute to health and a suitable basis for intake of health related compounds [14,16-18,26].

While comparing content of various compounds in different crops, presented in a wide array of studies including those on genetic variation, farming practices, and food and nutrition, a large variation is clearly seen (Table 1). Thus, spinach is a good source of iron and zinc while sea buckthorn and rose hips are good sources of vitamin A and E, and black currant is a good source of phenols (Table 1). However, variation is not only seen between various crops but also within specific crops (Table 1). Variation within the crop is the result of variation in genotype, various parts of the crop, between various harvest timing or cultivation places, various colors of the crop or specific breeding activities that have been carried out [8,9,24,27-57]. Among the latter, genetic modifications of the crop to increase production of a certain compound can be mentioned, e.g., Golden Rice [42,43]. The large variation within a specific crop also results in different requirements for intake of a crop to reach recommended daily intake. Table 2 shows how large a part of the recommended daily intake a certain amount of the crops (with their within crop variation) can contribute as related to certain compounds, when the contribution is calculated from the large variations reported in Table 1. As can be seen from Table 2, total daily requirements of zinc and iron can be reached by consumption of one liter of certain cereals or lentils. However, lentils or cereals are seldom consumed in amounts of one liter a day. Lentils are more commonly consumed in amounts of $\mathrm{dL}$ and cereals are mainly eaten as products, e.g., as bread, where one liter of wheat flour is almost enough for two bread loaves, and most of the nutritionally important components are found in the outer layers of the cereal grains, normally not included in the white wheat flour. For vitamin A (pro-vitamin A) or carotenoids, the understanding of human requirements is more complicated. In Tables 1 and 2 the numbers for various crops are given as total carotenoids. As to requirements, $0.6 \mathrm{mg}$ of vitamin A has been reported [22], although only some of the totally 700 carotenoids (around 50 in the human diet) are precursors of 
vitamin A [58]. The daily intake of carotenoids has been reported to vary between 9 and $16 \mathrm{mg}$ [59], so in addition to the requirement of $0.6 \mathrm{mg}$ of vitamin A there is most likely requirements of other carotenoids as well as other promoting factors, although the exact amounts are scarcely known. Daily consumptions of 3.3, 2.2 and $1.8 \mathrm{mg} \beta$-carotene, lycopene and lutein are reported from an investigation on a Swiss population [47]. As to vitamin E and tocopherols, data in the present paper is built on vitamin E activity, while e.g wheat is known to contain rather high levels of tocotrienols, although without vitamin E activity, but highly relevant for health on other aspects [9].

Table 1. Variation in content of Iron (Fe; $\mathrm{mg} / \mathrm{kg})$, Zinc $(\mathrm{Zn} ; \mathrm{mg} / \mathrm{kg})$, Total Carotenoids (Caro; mg/kg), Vitamin E activity (Vit E; mg/kg) and Total Phenolics (Phe, mg/kg) in a number of representative fruits, berries, vegetables, legumes and cereals.

\begin{tabular}{llllll}
\hline \multirow{2}{*}{ Crop } & \multicolumn{5}{l}{ Amount of Nutritionally Important Compounds } \\
\cline { 2 - 6 } & Fe & Zn & Caro & Vit E & Phe \\
\hline Apple & $2-16[29]^{*}$ & $1-3[29]$ & & $<0.1[40]$ & $692-1,212[49]$ \\
Orange & $1-16[29]$ & $2-10[29]$ & & $<0.1[40]$ & $1,080-1,170[24]$ \\
Banana & $6-20[3]^{\circ}$ & $4-11[3]^{\circ}$ & $1-94[41]$ & $<0.1[40]$ & $1,060-1,190[24,50]$ \\
Black Currant & $1-2[31]$ & $0.2-0.4[31]$ & $60-70[44]$ & & $19,200-31,800[51]$ \\
Strawberry & $3-7[32]$ & $1-2[32]$ & $0.5[56]$ & $<0.1[40]$ & $2,230-2,270[24]$ \\
Sea Buckthorn & $4-10[33]$ & $24-38[33]$ & $120-1,425[45]$ & $324-452[37]$ & $21,310-55,380[60]$ \\
Rose Hips & $11-118[34]$ & $7-14[34]$ & $42-1,024[46]$ & $110-205[38]$ & $59,210-122,390[61]$ \\
Carrots & $33-37[35]$ & $24-38[35]$ & $10-90[47]$ & $<0.1[40]$ & $83-85[24]$ \\
Tomato & $0.5-1.4[53]$ & $0.1-0.3[53]$ & $80-90[47]$ & $<0.1[40]$ & $235-239[24]$ \\
Spinach & $188-1,255[54]$ & $40-141[54]$ & $110-160[47]$ & & $322-329[24]$ \\
Pea & $4-5[36]$ & $2-4[36]$ & & $<0.1[40]$ & \\
Lentils & $63-105[55]$ & $32-39[55]$ & & & \\
Wheat & $18-38[8]$ & $21-39[8]$ & $3-4[57]$ & $6-12[9]$ & $2,710-3,016[57]$ \\
Rice & $1-27[27]$ & $13-44[27]$ & $1-37[43]$ & $17-24[39]$ & $146-4,222[48]$ \\
Maize & $11-34[28]$ & $14-45[28]$ & $1-34[42]$ & & \\
Oats & $45-46[52]$ & $29-31[52]$ & & & \\
\hline
\end{tabular}

Note: * Superscripts indicate the reference from where the data is collected, and data collected represents variation in amounts due to genetic variation, farming conditions, sample variation, genetic modifications, etc.

\section{Comparison of Compounds in Organic and Conventional Crops}

As mentioned in previous subchapter of this paper, a large variation is seen for nutritionally important compounds in food crops dependent on genotype evaluated, place, year and cultivation practices, part of the crop analyzed etc. In a number of previous publications, environmental variation including farming practices have been found as important as genetic variation in determining various components in a crop [62-67]. Thus, how the crop is cultivated seems as an important parameter in terms of content of nutritionally important compounds in a crop, and one such change in cultivation practices is organic cultivation instead of conventional. Thus, to verify or reject the hypothesis, that organically grown crops are nutritionally better for human, we will here review the up-to date present results according to influence of organic cultivation on nutritionally important compounds as defined above. 
Table 2. Daily requirements of some nutritionally important compounds and examples of weight (g) of a certain amount of the various representative crops, and the resulting amount and relative amount in relation to daily requirements of the various nutritionally important compounds (Iron (Fe), Zinc (Zn), Total Carotenoids (Caro), Vitamin E (Vit E) and Total Phenolics (Phe)) from consumption of these weights of the crops.

\begin{tabular}{|c|c|c|c|c|c|c|c|c|c|c|c|}
\hline \multirow{3}{*}{ Crop } & \multirow{3}{*}{ Weight (g) } & \multicolumn{10}{|c|}{ Nutritionally Important Compounds } \\
\hline & & \multicolumn{2}{|c|}{$\mathbf{F e}$} & \multicolumn{2}{|c|}{ Zn } & \multicolumn{2}{|c|}{ Caro } & \multicolumn{2}{|c|}{ Vit E } & \multicolumn{2}{|c|}{ Phe } \\
\hline & & Intake (mg) & $\%$ of Req & Intake (mg) & $\%$ of Req & Intake (mg) & $\%$ of Req & Intake (mg) & $\%$ of Req & Intake (mg) & $\%$ of Req \\
\hline \multicolumn{2}{|l|}{ Daily requirements (mg) } & \multicolumn{2}{|c|}{$10[23]$} & \multicolumn{2}{|c|}{$10[23]$} & \multicolumn{2}{|c|}{$0.6[22]$ (Vit A) } & \multicolumn{2}{|c|}{$10[22]$} & \multicolumn{2}{|c|}{$500[24]$} \\
\hline 1 Apple & $125-150[68]$ & $0.2-2.4$ & $2.5-24$ & $0.1-0.4$ & $1.2-4.5$ & & & $<0.02$ & $<0.2$ & $83-181$ & $16-36$ \\
\hline 1 Orange & $175[68]$ & $0.2-2.8$ & $1.8-28$ & $0.3-1.7$ & $3.5-17$ & & & $<0.02$ & $<0.2$ & $189-205$ & $37-41$ \\
\hline 1 Banana & $150[68]$ & $0.2-3.0$ & $2.0-30$ & $0.6-1.6$ & $6.0-16$ & $0.1-14$ & $17->100$ & $<0.01$ & $<0.1$ & $159-178$ & $31-36$ \\
\hline $1 \mathrm{~L}$ Black Currant berries & $500[68]$ & $0.5-1.0$ & $5.0-10$ & $1.0-2.0$ & $10-20$ & $3.0-3.5$ & $>100$ & & & $9,600-15,900$ & $>100$ \\
\hline $1 \mathrm{~L}$ Strawberries & $500[68]$ & $1.5-3.5$ & $15-35$ & $0.5-1.0$ & $5-10$ & 0.02 & 3.3 & $<0.05$ & $<0.5$ & $1,115-1,135$ & $>100$ \\
\hline 10 Sea Buckthorn berries & $12.5-14.3$ & $0.1-0.1$ & $5.0-14$ & $0.3-0.5$ & $3.0-3.5$ & $1.5-20$ & $>100$ & $4.1-6.5$ & $41-65$ & $266-791$ & $53->100$ \\
\hline 10 Rose Hips & $14-80$ & $0.1-9.4$ & $15-94$ & $0.1-1.1$ & $1.0-11$ & $0.6-82$ & $>100$ & $1.5-16.4$ & $15->100$ & $829-9,791$ & $>100$ \\
\hline 1 Carrots & $75-100[68]$ & $2.5-3.7$ & $25-37$ & $1.8-3.8$ & $18-38$ & $0.7-9$ & $>100$ & $<0.01$ & $<0.1$ & $6.2-8.5$ & $1.2-1.7$ \\
\hline 1 Tomato & $80[68]$ & $<0.1$ & $<1.1$ & $<0.02$ & $<0.2$ & $6.4-7.2$ & $>100$ & $<0.01$ & $<0.1$ & $18.8-19.1$ & $3.7-3.8$ \\
\hline 1 L Peas & $800[68]$ & $3.2-4.0$ & $32-40$ & $1.6-3.2$ & $16-32$ & & & $<0.08$ & $<0.8$ & & \\
\hline 1 L Lentils & $800-900[68]$ & $50-94$ & $>100$ & $25-35$ & $>100$ & & & & & & \\
\hline $1 \mathrm{~L}$ Wheat & $800[68]$ & $14-30$ & $>100$ & $17-31$ & $>100$ & $2.4-3.2$ & $>100$ & $4.8-9.6$ & $48-96$ & $2,168-2,412$ & $>100$ \\
\hline 1 L Rice & $720-850[68]$ & $0.7-23$ & $7 \rightarrow 100$ & $9-37$ & $90->100$ & $0.7-31$ & $>100$ & $12-20$ & $>100$ & $105-3,588$ & $21->100$ \\
\hline 1 L Maize & $750-800[68]$ & $8-27$ & $80->100$ & $10-36$ & $>100$ & $0.7-27$ & $>100$ & & & & \\
\hline
\end{tabular}

Notes: * Upper-case numbers indicate number of reference from where the data is collected. Numbers without upper-case numbers are calculated based on data in Table $1 . \%$ of Req $=$ Percentage of daily requirement. 
Upon reviewing the literature on the content of various compounds in organic and conventional crops, it quickly becomes obvious that conclusions from such comparisons are not easily drawn. One issue in such comparisons is whether the studies were carried out accurately. The importance of comparing crops where the only difference is the cultivation system and not variation in cultivation locations, attributes of the soil, eventual irrigation, whether, crop varieties, harvesting conditions, storage methods etc., have been stated by a number of authors [69-74]. However, the need of both holistic approaches and reductionist research is commonly pointed out from the organic research society [75], as is the need of research specifically on genotypes suitable for organic production, avoiding studies comparing conventional bred genotypes in conventional and organic systems $[76,77]$. In our compilation below of results from a wide array of studies related to comparisons of compounds in organic and conventional crops, we have chosen to conclude whether the cited literature stated presence of differences due to farming system applied. We have also chosen to comment on the methodology selected for the comparison in those cases where the studies claim the existence of differences.

As to variation in micronutrients including iron and zinc, comparisons of contents between organically and conventionally grown crops, have been carried out for almost any crop including e.g., strawberries, tomatoes, haricot beans, cotton, wheat, wheat flour, etc. [52-55,78-82]. The results from these studies shows sometimes a higher content of iron and zinc in the organically produced crops compared to the conventionally grown ones [78,82], however, sometimes the results are the opposite $[52,78,79]$ or there is no statistical difference between the two cultivation systems [53,79-81]. The studies showing higher contents of iron and zinc in the organically produced crops $[78,82]$, were not comparative but were based on purchased food from the market. However, some comparative studies have evaluated a number of organic fertilizing strategies and have been able to differentiate certain organic fertilization strategies as resulting in increased levels of iron and zinc in the crops [54,55]. As a whole, this study agrees with previous reviews e.g., [80], concluding that results from various studies are too diverse for a clear recommendation on what cultivation practices should be used for high iron and zinc levels. Other factors, like type of crop, year, place, environment, harvest timing, etc., seem to be of higher importance than organic cultivation. However, as pointed out by Hussain et al. [8], high content of minerals was found in organically grown wheat of certain genetic background and grown in a certain environment. Thus, it is important to select not only organic farming, but also "the right" genotypes and cultivation environments if high contents of iron and zinc are to be obtained.

Similarly, a number of studies comparing content of total carotenoids, certain carotenoids and/or vitamin A between various crops grown organic and conventionally have been carried out, e.g., in wheat, green cauliflower, tomatoes, sweet red bell pepper, grapefruit, grapes, apples and carrots [53,56,57,83-93]. The main conclusion from almost all studies correspond with previous reviews within the topic [74], i.e. that almost no significant differences in content of carotenoids of any type was found in crops from the two different farming systems [53,56,57,83-93]. Also, no increased plasma levels of lycopene were noted from consumption of organically produced tomatoes compared to conventionally produced ones [94]. In general, weather, environment and genotype seem to play a larger role for the carotenoid content than the farming system [74]. 
Quite a number of publications have evaluated the relationship between tocopherols content as related to organic versus conventional farming. A range of different crops have been evaluated in these studies including wheat, barley, rice, strawberries, peach, pears, plums, olives, sunflower, potatoes, fava beans [10,57,93,95-101]. Generally, the results from most investigations showed no difference in the content of tocopherols in the crops dependent on the farming system applied [10,57,93,97-99]. Also, for human health biomarkers, e.g. plasma IgG levels, no evidence of higher value from either of the two farming systems were detected [102]. However, some exceptions as to tocopherol contents were noted in the literature: (i) an overall higher content in total tocochromanol content and a change to a higher tocotrienol/tocopherol ratio were found for organically grown barley as compared to conventionally grown barley [96], (ii) higher contents of $\alpha$-, and $\gamma$-tocopherols in organic plums as compared to conventional plums, especially when grown on natural covered meadow soil [100], and (iii) a higher $\alpha$-tocopherol content in organic pears as compared to conventionally grown pears [101]. In the three mentioned cases [96,100,101], when differences were found for tocopherols related to the farming system, the experiments had been carried out comparatively, on the same farm or maximum up to $800 \mathrm{~m}$ apart, although, field conditions differed somewhat.

Similarly as for the above mentioned micronutrients and bioactive compounds, a large number of studies are available comparing levels of total phenolics as well as of individual phenolic compounds for a large number of crops. Examples of crops evaluated as to various phenolic compounds (or total phenolics) in organic and conventional farming systems are; wheat, maize, oats, potatoes, marionberries, strawberries, blueberries, black currant, peach, pear, apple, kiwi, tomatoes, leaf lettuce, collards, pac choi [92,101,103-119]. Compared with the micronutrients and bioactive compounds discussed above, phenolic compounds seem to be more influenced by the farming system used. Also for phenolics, there are studies with no significant difference in amounts or composition between crops grown conventionally vs. organically. However, a number of studies report higher values of various phenolic compounds in organic farming compared to conventional farming systems [101,104,105,107,110-114,116-118]. Most of the mentioned studies are comparative, with cultivations either on the same farm or on fields nearby each other. In two studies $[113,116]$, the experiments are carried out on organic and conventional commercial farms. The higher levels of phenolic compounds in organically grown crops have been attributed to the soil organic matter in organically farmed soils. Organic soils are known to have higher microbial biomass and activity, higher biodiversity and more biogeochemical processes [120]. However, the higher levels of phenolic compounds in organic agriculture have also been related to defense mechanisms in the organically grown crops against diseases and pests [104,121].

Thus, to conclude, no clear benefits as to content of the above defined nutritional important compounds could be seen in organically grown crops as compared to conventionally grown crops, with one possible exception, phenolic compounds. Other parameters seem of much higher importance, including selection of genotype, cultivation place, weather and year, harvest time and parts of the crop used. One issue that might be a problem in the evaluations carried out is that mostly cultivars developed for conventional cultivation have been evaluated, and some studies point on the fact that there are clear interaction effects between the selection of plant material and the farming practices [76,77]. Thus, to increase amount of nutritionally important compounds, selection and breeding of suitable genotypes in combination with organic farming might be preferable. Large changes in content of a 
specific nutritionally important compound has been found in genetically modified crops, e.g., those developed for high $\beta$-carotene (pro-vitamin A) content in rice and maize.

\section{Additional Human Health Related Issues in Crops-Chemicals and Heavy Metals}

As mentioned above, organic agriculture does not use synthetic pesticides. Thus, pesticide residues in the food or crop might be one difference between conventional and organic products, which might influence public health. In Germany, a thorough screening of food for active substances of pesticides has been carried out, and a total of 361 active pesticide substances were found, $60.2 \%$ of the samples had residues of at least one pesticide and $40,7 \%$ had residues of more than one. Table grapes showed the highest numbers of different pesticide residues with 23 substances and in several of the apple, oranges and pear samples 10-12 substances were found [122]. Several studies have indicated that pesticide residues in the food may contribute to the development of cancer, Parkinson's disease, and endocrine related disorders [123-127].

Urinary biomonitoring has been used to evaluate dietary organophosphorus pesticide exposure among children, and showed that a substitution into organic food for five consecutive days decreased two specific metabolites, malathion and chlorpyrifor, to undetectable levels [128]. Furthermore, children who consumed exclusively organic produce showed no measurable pesticide metabolites [129].

As to heavy metals in crops and crop-based food, some literature states that the contents do not differ significantly as related to if the applied farming system has been organic or conventional [130]. However, when screening the literature and investigations on various crops and crop-based food from the two systems, there is a number of studies showing higher contents of heavy metals and especially cadmium from conventional grown products than from organic ones e.g., [131-137]. A few studies also report on higher cadmium $(\mathrm{Cd})$ and lead $(\mathrm{Pb})$ levels in organic tomatoes, but lower levels of $\mathrm{Cu}$ as compared to conventional ones [138], and higher levels of nickel, $\mathrm{Pb}$ and zinc $\mathrm{Zn}$ ) in organic wheat, as compared to conventional [131]. One explanation for higher levels of heavy metals in conventional than organic crops and crops based food might be the higher levels of $\mathrm{Cd}$, copper and $\mathrm{Zn}$ in inorganic fertilizers that commonly have been used, although presence of heavy metals in conventional fertilizers has been reduced during recent years [139]. Similarly as for the nutritional compounds discussed above, a large variation in heavy metal accumulation among genotypes, also when organically grown, have been reported [140].

\section{Health Biomarkers in Whole Organisms and in vitro Studies}

In addition to estimations of the content of individual compounds in different organic $v s$. conventionally cultivated crops, investigations have been performed on the effects of health biomarkers in whole organisms, or effects studied in in vitro systems. These experiments may represent a more holistic approach and also comprise synergistic effects between different compounds, which otherwise might be difficult to investigate and evaluate. In different animal experiments, investigated effects of organic or conventional feed have mainly concerned two areas; fertility/reproduction and the immune system. Early studies, starting as early as 1926, investigated the outcome when organic fertilizers were compared with mineral, and found differences in growth rate 
(rats, two studies), pup survival rate (mice), reproduction (chicken), and fertility (bulls, rabbits), though three studies found no differences in growth rate or fertility [141]. Similarly, more recent studies have found differences on animals fed with organic versus conventionally grown feed, although in some studies no significant differences were observed. Positive results from organic feed were found for reproductive performance in rabbits [142], immune status in rats and chicken [143,144], resulting in stimulated proliferation of lymphocytes in rats if fed with protein shortage [133], higher levels of $\alpha$-tocopherol and immunoglobulin $G$ in blood serum [145], higher splenocyte proliferation in male rats [146], increase in regulatory $\mathrm{T}$ cells in mice [147], enhanced immune reactivity, a stronger reaction to the immune challenge as well as a slightly stronger "catch-up growth" after the challenge in chicken [143]. Recently also the well characterized fruit fly, Drosophila melanogaster, was used in experiments with organic and conventional feed. Flies raised on diets made from organic produce (bananas, potatoes, raisins, soy beans) had greater fertility and longevity than those raised on conventional produce [148].

Interestingly, several studies with mice, rats, rabbits and hen, have reported that animals can discriminate between organic and conventional feed in food preference tests and prefer organic produce $[141,149,150]$.

Conducting long-term human studies has some obvious difficulties. Often preference for organically produced food is associated with a healthy and active life style [151], which has recently been emphasized in a follow-up study on the large Nutrinet-Santé cohort, comprising 54,311 adults [152]. The study concluded that consumers of organic products were more highly educated, more physically active, exhibited dietary patterns including more plant food and less sweet and alcoholic beverages, as compared with those not interested in organic products [152]. Most human short-term intervention studies have shown no significant difference for people eating conventional or organic food. Thus, no significant difference was found in total antioxidant activity, serum LDL oxidation or total phenol content in humans consuming organic versus conventional Cabernet Sauvignon wine [153], in serum glucose, triacylglycerol and uric acid, LDL antioxidant capacity and lymphocyte damage in humans consuming apples [154], polyphenol and carotenoid concentration in humans consuming apples and carrots, and LDL oxidation and some immune factors in humans consuming carrots $[155,156]$. However, urinary excretions of quercetin and kaempferol were higher after consumption of organic diet [157], and consumption of organic dairy products, but not organic diet, reduced risk of eczema among children [158]. Children eating an antroposophic diet in an observational study, as compared with conventional diet, had lower body weight and exhibited fewer allergies [159]. The discrepancy between the outcome of the animal studies, showing a rather wide array of positive effects of organic food, and the short-term human studies, only showing a few positive effects, has resulted in questions related to planning and performance of human studies. Many studies have tried to find reliable biomarkers for health, and recent animal feeding studies have had as an aim to define disease risk and health effects' biomarkers usable for future human studies [145,160]. However, still there is only a limited number of human studies available having investigated the effects of consumption of organic food on health, disease risks' and health promoting compounds, and the development of reliable biomarkers to be used in such studies are still in its infancy [161,162]. Therefore, as we today routinely accept animal experiments for assessing the risk of toxic food substances, to study absorption, metabolism and function of nutrients, as well as investigating beneficial effects of components in food, 
it seems reasonable that the positive results of the animal feeding experiments with organic food can be considered as a good indication of that there might be health benefits of consumption of organic food also for humans.

In vitro studies have shown that fruit and berry extracts inhibit cancer cell proliferation [163]. Thus, constituents from fruits and especially berries seem to affect cancer progression cellular processes [164]. Also, extracts from strawberries were found to inhibit cancer cell proliferation rate and extracts from organic strawberries to a higher degree than extracts from conventionally produced strawberries [165]. Despite these findings, most literature indicates that there is no proof of specific compounds, nor of high antioxidant activity contributing to anticancer activity [166]. This means that the exact mechanisms behind the anticancer activities seen in in vitro studies from berries are still not known, although further in vitro studies and models might contribute to increased understanding of mechanisms [167].

\section{Conclusions-Do Organically Produced Crops Contribute to Human Health?}

Both animal studies and in vitro studies clearly indicate the benefits of consumption of organically produced food instead of that conventionally produced. Investigations on humans are scarce and only few of those performed can confirm positive public health benefits while consuming organic food. However, animal experiments are today routinely used to assess impact on humans in various other aspects and thus, the positive effects on animal from consumption of organically produced food can be regarded as an indication of positive effects also on humans. The reasons why organically produced food contributes to public health are unclear, as specific high amounts of nutritionally high value compounds with high antioxidant capacity does not seem to be the key for improved public health from organic food consumption. Instead synergistic effects of several constituents might be the back-ground for the possible positive effects of organic food, as well as absence of pesticide residues. The present review also did not find higher contents of nutritional beneficial compounds, with the exception of phenolic compounds, as an answer to increased amounts of pathogens, in organically cultivated crops than in conventionally cultivated ones. Some previous studies have indicated a higher vitamin $\mathrm{C}$ content in organically produced crops as compared to conventionally ones [107], as a response to increased amounts of pathogens [107]. Vitamin C might be part of the synergistic constituents contributing to prevention against oxidation of other compounds although vitamin $C$ in itself was not found to protect against proliferation of cancer cells [149]. Extremely large variation of nutritional beneficial compounds was found in crops due to various reasons, and parameters contributing to the variation were: genotypes, farming conditions, environment, harvest time, crop part and genetic modifications of the crop. The highest values of specific nutritional compound were seen in specific genotypes and high increases were seen for genetically modified crops. These crops with very high values of certain compounds could be of relevance for cultivation and production of food in areas with a large deficit in that specific compound in the diet. For a general improvement in public health, it however, seems more relevant to focus on combining a "right" genotype with a "right" farming system, were organic farming could be an alternative. From this "right" system, a crop based food should then be obtained with the "right" cocktail of constituents to obtain the synergistic effect that was reported from organically produced fruits and 
berries as related to cancer cell proliferation. The low amounts of pesticide residues and heavy metals reported in organically produced crops might be one part of the reported bases for an anticancer effect of organic food. The reasons for an eventual positive effect of consumption of organic crop-based foods on public health are summarized in Figure 1. Besides the impact on public health through possible positive effects of consumption of organic food, public health might also be influenced through organic cultivation due to its environmental effects, which are not discussed in the present review.

Figure 1. Interactive model showing proof of concept for interaction of different factors resulting in a possible positive impact on human health by organic crop based food.

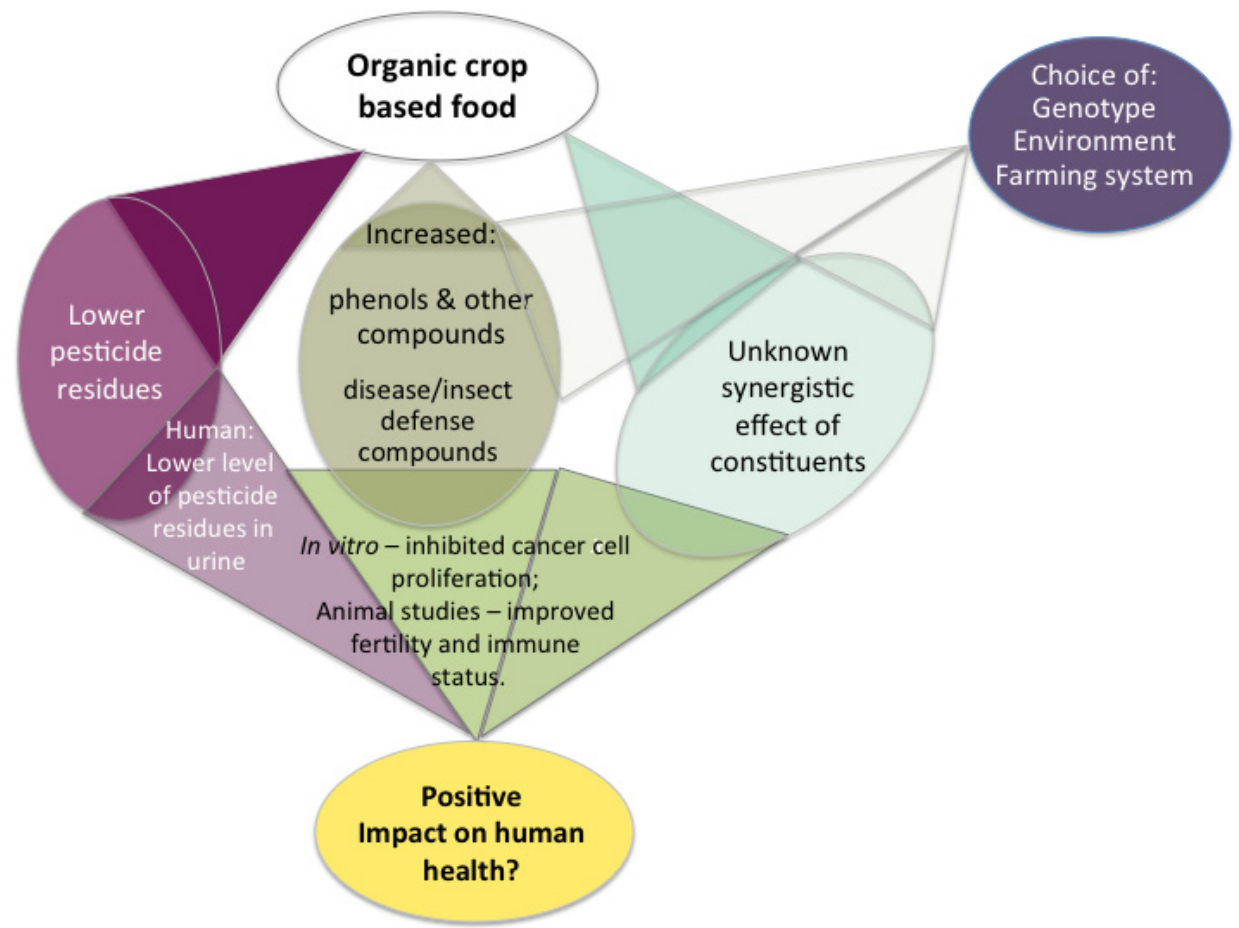

\section{Acknowledgements}

We thank the governmental research program Trees and Crops for the Future (TC4F), VINNOVA, Ekoforsk and Ekhaga foundation for financial support; and Higher Education Commission, Pakistan, for financial support to Abrar Hussain.

\section{Author Contributions}

All authors planned the manuscript jointly and participated in discussions of the manuscripts as well as commented the various drafted text versions of the manuscript. Eva Johansson came up with the idea of the manuscript and also did the main part of the writing and compilation of various parts of the manuscript. The rest of the authors took the main responsibility for different parts of the manuscript, i.e., Abrar Hussain for Section 1, Staffan Andersson for Section 2, Ramune Kuktaite for Section 4 and Figure 1 and Marie Olsson of subchapter 6. The various parts were thereafter reshaped by the first author in order to follow the same style and the style of the journal. 


\section{Conflicts of Interest}

There are no conflicts of interest with the results of this manuscript.

\section{References}

1. Lotter, D. Organic agriculture. J. Sustainable Agr. 2003, 21, 59-128.

2. Food and Agriculture Organization. Organic Agriculture. Available online: http://www.fao.org/ unfao/bodies/COAG/COAG15/X0075E.htm\#P99_8218 (accessed on 7 December 2013).

3. International Federation of Organic Agriculture Movements (IFOAM). IFOAM International Federation of Organic Agriculture Annual Report 2007; International Federation of Organic Agriculture Movements: Bonn, Germany, 2007.

4. United States Department of Agriculture (USDA). Report and Recommendations on Organic Farming; United States Department of Agriculture: Washington, DC, USA, 1980.

5. United States Department of Agriculture (USDA). Organic Agriculture. Organic Policy. Available online: http:/www.ers.usda.gov/topics/natural-resources-environment/organic-agriculture/ organic-policy.aspx (accessed on 20 December 2013).

6. European Comission. European Action Plan for Organic Farming. Available online: http://ec.europa.eu/agriculture/organic/eu-policy/action-plan_en (accessed on 20 December 2013).

7. Willer, H.; Kilcher, L. The World of Organic Agriculture-Statistics and Emerging Trends 2012; Research Institute of Organic Agriculture (FiBL), International Federation of Organic Agriculture Movements (IFOAM): Bonn, Germany, 2012.

8. Hussain, A.; Larsson, H.; Kuktaite, R.; Johansson, E. Mineral composition of organically grown wheat genotypes: Contribution to daily minerals intake. Int. J. Environ. Res. Public Health 2010, 7, 3442-3456.

9. Hussain, A.; Larsson, H.; Olsson, M.E.; Kuktaite, R.; Grausgruber, H.; Johansson, E. Is organically produced wheat a source of tocopherols and tocotrienols for health food? Food Chem. 2012, 132, 1789-1795.

10. Hussain, A.; Larsson, H.; Kuktaite, R.; Johansson, E. Healthy food from organic wheat: Choice of genotypes for production and breeding. J. Sci. Food Agr. 2012, 92, 2826-2832.

11. Benbrook, C.; Zhao, X.; Yáñez, J.; Davies, N.; Andrews, P. New Evidence Confirms the Nutritional Superiority of Plant-based Organic Foods. Available online: http://www.organic -center.org (assessed on 20 December 2013).

12. World Health Organization. Diet, Nutrition and the Prevention of Chronic Diseases; WHO: Geneva, Switzerland, 2003.

13. Welch, R.M. The impact of mineral nutrients in food crops on global human health. Plant Soil 2002, 247, 83-90.

14. Grusak, M.A.; DellaPenna, D. Improving the nutrient composition of plants to enhance human nutrition and health. Annu. Rev. Plant. Physiol. Plant Mol. Biol. 1999, 50, 133-161.

15. Welch, R.M.; Graham, R.D. Breeding for micronutrients in staple food crops from a human nutrition perspective. J. Exp. Bot. 2004, 55, 353-364. 
16. Bazzano, L.A.; He, J.; Ogden, L.G.; Loria, C.M.; Vupputuri, S.; Myers, L.; Whelton, P.K. Fruit and vegetable intake and risk of cardiovascular disease in US adults: The first national health and nutrition examination survey epidemiologic follow-up study. Amer. J. Clin. Nutr. 2002, 76, 93-99.

17. Slavin, J. Whole grains and human health. Nutr. Res. Rev. 2004, 17, 99-110.

18. Tharanathan, R.N.; Mahadevamma, S. Grain legumes-A boon to human nutrition. Trends Food Sci. Technol. 2003, 14, 507-518.

19. Traber, M.G.; Sies, H. Vitamin E in humans: Demand and delivery. Ann. Rev. Nutr. 1996, 16, 321-347.

20. Mattoo, A.K.; Shukla, V.; Fatima, T.; Handa, A.K.; Yachha, S.K. Genetic engineering to enhance crop-based phytonutrients (nutraceuticals) to alleviate diet-related diseases. Adv. Exp. Med. Biol. 2010, 698, 122-143.

21. Pinheiro, M.M.; Ciconelli, R.M.; Chaves, G.V.; Aquino, L.; Juzwiak, C.R.; Genaro, P.D.; Ferraz, M.B. Antioxidant Intake among Brazilian adults-The Brazilian osteoporosis study (BRAZOS): A cross-sectional study. Nutr. J. 2011, 10, doi:10.1186/1475-2091-10-39.

22. Recommended Daily Intake of Vitamins and Minerals. Available online: http://www.lenntech.com/ recommended-daily-intake.htm (assessed on 27 January 2014).

23. German Nutrition Society. Referenzwerte. fur die Nährstoffzufuhr, 1. Auflage, 1st ed.; Umschau/Braus: Frankfurt, Germany, 2001.

24. Chun, O.K.; Kim, D.-O.; Smith, N.; Schroeder, D.; Han, J.H. Daily consumption of phenolics and total antioxidant capacity from fruit and vegetables in the American diet. J. Sci. Food Agr. 2005, 85, 1715-1724.

25. Bjelakovic, G.; Nikolova, D.; Gluud, C. Antioxidant supplements and mortality. Curr. Opin. Clin. Nutr. Met. Care 2014, 17, 40-44.

26. Omenn, G.S.; Goodman, G.E.; Thornquist, M.D.; Balmes, J.; Cullen, M.R.; Glass, A.; Keogh, J.P.; Meyskens, F.L.; Valanis, B.; Williams, J.H.; Barnhart, S.; Hammar, S. Effects of a combination of beta carotene and vitamin A on lung cancer and cardiovascular disease. N. Engl. J. Med. 1996, 334, 1150-1155.

27. Jiang, S.L.; Wu, J.G.; Thang, N.B.; Feng, Y.; Yang, W.E.; Shi, C.H. Genotypic variation of mineral elements contents in rice (Oryza. sativa L.). Eur. Food Res. Technol. 2008, 228, 115-122.

28. Menkir, A. Genetic variation for grain mineral content in tropical-adapted maize inbred lines. Food Chem. 2008, 110, 454-464.

29. Özcan, M.M.; Harmankaya, M.; Gezgin, S. Mineral and heavy metal contents of the outer and inner tissues of commonly used fruits. Environ. Monit. Assess. 2012, 184, 313-320.

30. Davey, M.W.; van den Bergh, I., Markham, R.; Swennen, R.; Keulemans, J. Genetic variability in Musa fruit provitamin A carotenoids, lutein and mineral micronutrient contents. Food Chem. 2009, 115, 806-813.

31. Nour, V.; Trandafir, I.; Ionica, M.E. Ascorbic acid, anthocyanins, organic acids and mineral content of some black and red currant cultivars. Fruits 2011, 66, 353-362.

32. Wasim, M.; Khalid, N.; Asif, A.; Arif, M.; Zaidi, J.H. Elemental characterization of strawberry grown in Islamabad by $k_{0}$-instrumental neutron activation analysis and atomic absorption spectrophotometry and its dietary assessment. J. Radioanal. Nucl. Chem. 2012, 292, 1153-1159. 
33. Ercisli, S.; Orhan, E.; Ozdemir, O.; Sengul, M. The genotypic effects on the chemical composition and antioxidant activity of sea buckthorn (Hippophae rhamnoides L.) berries grown in Turkey. Sci. Hort. 2007, 115, 27-33.

34. Kazaz, S.; Baydar, H.; Erbas, S. Variations in chemical compositions of Rosa damascene Mill. and Rosa canina L. fruits. Czech. J. Food Sci. 2009, 27, 178-184.

35. Smolen, S.; Wlodzimierz, S.; Rozek, S.; Ledwozyw-Smolen, I.; Strzetelski, P. Preliminary evaluation of the influence of iodine and nitrogen fertilization on the effectiveness of iodine biofortification and mineral composition of carrot storage roots. J. Elem. 2011, 16, 275-285.

36. Wang, N.; Hatcher, D.W.; Gawalko, E.J. Effect of variety and processing on nutrients and certain anti-nutrients in field peas (Pisum. sativum). Food Chem. 2008, 111, 132-138.

37. Andersson, S.C.; Rumpunen, K.; Johansson, E.; Olsson, M.E. Tocopherols and tocotrienols in Sea Buchthorn (Hoppophae. rhamnoides) berries during ripening. J. Agric. Food Chem. 2008, 56, 6701-6706.

38. Andersson, S.C.; Olsson, M.E.; Gustavsson, K.-E.; Johansson, E.; Rumpunen, K. Tocopherols in rose hips (Rosa spp.) during ripening. J. Sci. Food Agric. 2012, 92, 2116-2121.

39. Heinemann, R.J.B.; Xu, Z.M.; Godber, J.S.; Lanfer-Marquez, U.M. Tocopherols, tocotrienols and gamma-oryzanol contents in Japonica and Indica subspecies of rice (Oryza sativa L.) cultivated in Brazil. Cereal Chem. 2008, 85, 243-247.

40. Chun, J.; Lee, J.; Ye, L.; Exler, J.; Eitenmiller,R.R. Tocopherol and tocotrienol contents of raw and processed fruits and vegetables in the United States diet. J. Food Compos. Anal. 2006, 19, 196-204.

41. Englberger, L.; Lyons, G.; Foley, W.; Daniells, J.; Aalbergsberg, B.; Dolodolotawake, U.; Watoto, C.; Iramu, E.; Taki, B.; Wehi, F.; Warito, P.; Taylor, M. Carotenoid and riboflavin content of banana cultivars from Makira Solomon Island. J. Food Compos. Anal. 2010, 23, 624-632.

42. Aluru, M.; Xu, Y.; Guo, R.; Wang, Z.; Li, S.; White, W.; Wang, K.; Rodermel, S. Generation of transgenic maize with enhanced provitamin A content. J. Exp. Bot. 2008, 59, 3551-3562.

43. Paine, J.A.; Shipton, C.A.; Chaggar, S.; Howells, R.M.; Kennedy, M.J.; Vernon, G.; Wright, S.Y.; Hinchliffe, E.; Adams, J.L.; Silverstone, A.L.; Drake, R. Improving the nutritional value of Golden Rice through increased pro-vitamin A content. Nature Biotech. 2005, 23, 482-487.

44. Tabart, J.; Kevers, C.; Evers, D.; Dommes, J. Ascorbic acid, phenolic acid, flavonoid, and carotenoid profiles of selected extracts from Ribes. nigrum. J. Agric. Food Chem. 2011, 59, 4763-4770.

45. Andersson, S.C.; Olsson, M.E.; Johansson, E.; Rumpunen, K. Carotenoids in sea buckthorn (Hippophae. rhamnoides L.) berries during ripening and use of pheophytin a as a maturity marker. J. Agric. Food Chem. 2009, 57, 250-258.

46. Andersson, S.C.; Rumpunen, K.; Johansson, E.; Olsson, M.E. Carotenoid content and composition in rose hips (Rosa spp.) during ripening, determination of suitable maturity marker and implications for health promoting food products. Food Chem. 2011, 128, 689-696.

47. Reif, C.; Arrigoni, E.; Schärer, H.; Nyström, L.; Hurrell, R.F. Carotenoid database of commonly eaten Swiss vegetables and their estimated contribution to carotenoid intake. J. Food Compos. Anal. 2013, 29, 64-72. 
48. Shao, Y.F.; Xu, F.F.; Sun, X.; Bao, J.S.; Beta, T. Phenolic acids, anthocyanins, and antioxidant capacity in rice (Oryza sativa L.) grains at four stages of development after flowering. Food Chem. 2014, 143, 90-96.

49. Volz, R.K.; McGhie, T.K. Genetic variability in apple fruit polyphenol composition in Malus $\times$ domestica and Malus sieversii germplasm grown in New Zealand. J. Agric. Food Chem. 2011, 59, 11509-11521.

50. Patthamakanokporn, O.; Puwastien, P.; Nitithamyong, A.; Sirichakwal, P.P. Changes of antioxidant activity and total phenolics compounds during storage of selected fruits. J. Food Compos. Anal. 2008, 21, 241-248.

51. Vagiri, M.; Ekholm, A.; Oberg, E.; Johansson, E.; Andersson, S.C.; Rumpunen, K. Phenols and ascorbic acid in black currants (Ribes nigrum L.): Variation due to genotype, location, and year. J. Agr. Food Chem. 2013, 61, 9298-9306.

52. Ciolek, A.; Makarska, E.; Wesolowski, M.; Cierpiala, R. Content of selected nutrients in wheat, barley and oat grain from organic and conventional farming. J. Elementol. 2012. 17, 181-189.

53. Ordonez-Santos, L.E.; Vazquez-Oderiz, M.L.; Romero-Rodriguez, M.A. Micronutrient contents in organic and conventional tomatoes (Solanum. lycopersicum L.). Int. J. Food Sci. Technol. 2011, 46, 1561-1568.

54. Citak, S.; Sonmez, S. Mineral contents of organically and conventionally grown spinach (Spinacea oleracea L.) during two successive seasons. J. Agr. Food Chem. 2009, 57, 7892-7898.

55. Gunes, A.; Inal, A.; Adak, M.S.; Alpaslan, M.; Bagci, E.G.; Erol, T.; Pilbeam, D.J. Mineral nutrition of wheat, chickpea and lentil as affected by mixed cropping and soil moisture. Nutr. Cycl. Agroecosyst. 2007, 78, 83-96.

56. Cardoso, P.C.; Tomazini, A.P.B.; Stringheta, P.C.; Ribeiro, S.M.R.; Pinheiro-Sant'Ana, H.M. Vitamin $\mathrm{C}$ and carotenoids in organic and conventional fruits grown in Brazil. Food Chem. 2011, $126,411-416$.

57. Konopka, I.; Tanska, M.; Faron, A.; Stepien, A.; Wojtkowiak, K. Comparison of the phenolic compounds, carotenoids and tocochromanols content in wheat grain under organic and mineral fertilization regimes. Molecules 2012, 17, 12341-12356.

58. Maiani, G.; Caston, M.J.P.; Catasta, G.; Toti, E.; Cambrodon, I.G.; Bysted, A.; Granado-Lorencio, F.; Olmedilla-Alonso, B.; Knuthsen, P.; Valoti, M. Carotenoids: Actual knowledge on food sources, intake, stability and bioavailability and their protective role in humans. Mol. Nutr. Food Res. 2009, 53, 194-218.

59. O’Neill, M.E.; Carroll, Y.; Corridan, B.; Olmedilla, B.; Granado, F.; Blanco, I.; van den Berg, H.; Hininger, I.; Rousell, A,M.; Chopra, M. A European carotenoid database to assess carotenoid intakes and its use in a five-country comparative study. Brit. J. Nutr. 2001, 85, 499-507.

60. Gao, X.; Ohlander, M.; Jeppsson, N.; Björk, L.; Trajkovski, V. Changes in antioxidant effects and their relationship to phytonutrients in fruits of sea Buckthorn (Hippophae. rhamnoides L.) during maturation. J. Agr. Food Chem. 2000, 48, 1485-1490.

61. Gao, X.; Björk, L.; Trajkovski, V.; Uggla, M.; Evaluation of antioxidant activities of rosehip ethanol extracts in different test systems. J. Sci. Food Agr. 2000, 80, 2021-2027. 
62. Johansson, E.; Prieto-Linde, M.-L.; Gissén, C. Influences of weather, cultivar and fertilizer rate on grain protein accumulation in field-grown wheat, and relations to grain water content and falling number. J. Sci. Food Agr. 2008, 88, 2011-2018.

63. Malik, A.H.; Prieto-Linde, M.L.; Kuktaite, R.; Andersson, A.; Johansson, E. Individual and interactive effects of cultivar maturation time, nitrogen regime and temperature level on accumulation of wheat grain proteins. J. Sci. Food Agr. 2011, 91, 2192-2200.

64. Francisco, M.; Cartea, M.E.; Soengas, P.; Velasco, P. Effect of genotype and environmental conditions on health-promoting compounds in Vrassica rapa. J. Agr. Food Chem. 2011, 59, 2421-2431.

65. Labuschagne, M.T.; Mkhatywa, N.; Wentzel, B.; Johansson, E.; van Biljon, A. Tocochromanol concentration, protein composition and baking quality of white flour of South African wheat cultivars. J. Food Compos. Anal. 2014, 33, 127-131.

66. Mpofu, A.; Sapirstein, H.D.; Beta, T. Genotype and environmental variation in phenolic content, phenolic acid composition, and antioxidant activity of hard spring wheat. J. Agr. Food Chem. 2006, 1265-1270.

67. Anttonen, M.J.; Karjalainen, R.O. Environmental and genetic variation of phenolic compounds in red raspberry. J. Food Compos. Anal. 2005, 18, 759-769.

68. Receptfavoriter. Available online: http://receptfavoriter.se/matartiklar/matt-och-vikt-pa-olikalivsmedel.html (assessed on 11 January 2014).

69. Lester, G.E.; Saftner, R.A. Organically vs. conventionally grown produce: common production inputs, nutritional quality, and nitrogen delivery between the two systems. J. Agr. Food Chem. 2011, 59, 10401-10406.

70. Harker, F.R. Organic food claims cannot be substantiated through testing of samples intercepted in the marketplace: A horticulturalist's opinion. Food Qual. Pref. 2004, 15, 91-95.

71. Huber, M.; Rembialkowska, E.; Srednicka, D.; Bugel, S.; van de Vijver, L.P.L. Organic food and impact on human health: Assessing the status quo and prospects of research. J. Life Sci. 2011, 58, 103-109.

72. Dangour, D.A.; Dodhia, S.K.; Hayter, A.; Allen, E.; Lock, K.; Uauy, R. Nutritional quality of organic foods: A systematic review. Amer. J. Clin. Nutr. 2009, 90, 680-685.

73. Woese, K.; Lange, D.; Boess, C.; Bogl, K.W. A comparison of organically and conventionally grown foods - Results of a review of the relevant literature. J. Sci. Food Agric. 1997, 74, 281-293.

74. Smith-Spangler, C.; Brandeau, M.L.; Hunter, G.; Clay Bavinger, J.; Pearson, M.; Echbach, P.J.; Sundaram, V.; Liu, H.; Schirmer, P.; Stave, C.; Olkin, I.; Bravata, D.M. Are organic foods safer or healthier than conventional alternatives? A systematic review. Annal. Int. Med. 2012, 157, 348-366.

75. Watson, C.A.; Walker, R.L.; Stockdale, E.A. Research in organic production systems—Past, present and future. J. Agric. Sci. 2008, 146, 1-19.

76. Murphy, K.M.; Campbell, K.G.; Lyon, S.R.; Jones, S.S. Evidence of varietal adaptation to organic farming systems. Field Crop. Res. 2007, 102, 172-177.

77. Van Bueren, E.T.L.; Struik, P.C.; Tiemens-Hulscher, M.; Jacobsen, E. Concepts of intrinsic value and integrity of plants in organic plant breeding and propagation. Crop. Sci. 2003, 43, 1922-1929. 
78. Vrcek, I.V.; Cepo, D.V.; Rasic, D.; Peraica, M.; Zuntar, I.; Bojic, M.; Mendas, G.; Medic-Saric, M. A comparison of the nutritional value and food safety of organically and conventionally produced wheat flours. Food Chem. 2014, 143, 522-529.

79. Kristl, J.; Krajnc, A.U.; Kramberger, B.; Mlakar, S.G. Strawberries from integrated and organic production: Mineral contents and antioxidant activity. Acta Chim. Slov. 2013, 60, 19-25.

80. Martinez-Ballesta, M.C.; Dominguez-Perles, R.; Moreno, D.A.; Muries, B.; Alcaraz-Lopez, C.; Bastias, E.; Garcia-Viguera, C.; Carvajal, M. Minerals in plant food: Effect of agricultural practices and role in human health: A review. Agron. Sustain. Dev. 2010, 30, 295-309.

81. He, Z.Q.; Shankle, M.; Zhang, H.; Way, T.R.; Tewolde, H.; Uchimiya, M. Mineral composition of cottonseed is affected by fertilization management practices. Agron. J. 2013, 105, 341-350.

82. Akbaba, U.; Sahin, Y.; Turkez, H. Comparison of element contents in haricot beans grown under organic and conventional farming regimes for human nutrition and health. Acta Scientiarum Polonorum-Hortorum Cultus 2012, 11, 117-125.

83. Lo Scalzo, R.; Picchi, V.; Migliori, C.A.; Campanelli, G. Variations in the phytochemical contents and antioxidant capacity of organically and conventionally grown Italian cauliflower (Brassica oleracea L. subsp botrytis): Results from a three-year field study. J. Agr. Food Chem. 2013, 61, 10335-10344.

84. Borguini, R.G.; Bastos, D.H.M.; Moita-Neto, J.M.; Capasso, F.S.; Torres, E.A.F.D. Antioxidant potential of tomatoes cultivated in organic and conventional systems. Braz. Arch. Biol. Technol. 2013, 56, 521-529.

85. Hallmann, E.; Rembialkowska, E. Characterisation of antioxidant compounds in sweet bell pepper (Capsicum annuum L.) under organic and conventional growing systems. J. Sci. Food Agric. 2012, 92, 2409-2415.

86. Chebrolu, K.K.; Jayaprakasha, G.K.; Jifon, J.; Patil, B.S. Production system and storage temperature influence grapefruit vitamin C, limonoids, and carotenoids. J. Agric. Food Chem. 2012, 60, 7096-7103.

87. Bunea, C.I.; Pop, N.; Babes, A.C.; Matea, C.; Dulf, F.V.; Bunea, A. Carotenoids, total polyphenols and antioxidant activity of grapes (Vitis vinifera) cultivated in organic and conventional systems. Chem. Central J. 2012, 6, 66.

88. Yuri, J.A.; Maldonado, F.J.; Razmilic, I.; Neira, A.; Quilodran, A.; Palomo, I. Concentrations of total phenols and antioxidant activity in apple do not differ between conventional and organic orchard management. J. Food Agr. Environ. 2012, 10, 207-216.

89. Picchi, V.; Migliori, C.; lo Scalzo, R.; Campanelli, G.; Ferrari, V.; di Cesare, L.F. Phytochemical content in organic and conventionally grown Italian cauliflower. Food Chem. 2012, 130, 501-509.

90. Soltoft, M.; Bysted, A.; Madsen, K.H.; Mark, A.B.; Bugel, S.G.; Nielsen, J.; Knuthsen, P. Effects of organic and conventional growth systems on the content of carotenoids in carrot roots, and on intake and plasma status of carotenoids in humans. J. Sci. Food Agr. 2011, 91, 767-775.

91. Stracke, B.A.; Ruefer, C.E.; Watzl, B. Polyphenol and carotenoid content of organically and conventionally produced apples (Malus domestica Bork., Elstar variety) and carrots (Daucus carota L., Narbonne and Nerac varieties). Ernahrungs Umschau 2010, 57, 526-531. 
92. Stracke, B.A.; Eitel, J.; Watzl, B.; Mader, P.; Rufer, C.E. Influence of the production method on phytochemical concentrations in whole wheat (Triticum aestivum L.): A comparative study. J. Agr. Food Chem. 2009, 57, 10116-10121.

93. Roose, M.; Kahl, J.; Ploeger, A. Influence of the farming system on the xanthophyll content of soft and hard wheat. J. Agr. Food Chem. 2009, 57, 182-188.

94. Caris-Veyrat, C.; Amiot, M.J.; Tyssandier, V.; Grasselly, D.; Buret, M.; Mikolajczak, M.; Guilland, J.C.; Bouteloup-Demange, C.; Borel, P. Influence of organic vs. conventional agricultural practice on the antioxidant microconstituent content of tomatoes and derived purees: Consequences on antioxidant plasma status in humans. J. Agr. Food Chem. 2004, 52, 6503-6509.

95. Ranalli, F.; Ranalli, A.; Contento, S.; Casanovas, M.; Antonucci, M.; di Simone, G. Bioactives and nutraceutical phytochemicals naturally occurring in virgin olive oil: The case study of the Nocellara del Belice Italian olive cultivar. Natural Prod. Res. 2013, 27, 1686-1690.

96. Tsochatzis, E.D.; Bladenopoulos, K.; Papageorgiou, M. Determination of tocopherol and tocotrienol content of Greek barley varieties under conventional and organic cultivation techniques using validated reverse phase high-performance liquid chromatography method. J. Sci. Food Agr. 2012, 92, 1732-1739.

97. Cho, J.Y.; Lee, H.J.; Kim, G.A.; Kim, G.D.; Lee, Y.S.; Shin, S.C.; Park, K.H.; Moon, J.H. Quantitative analyses of individual gamma-Oryzanol (Steryl ferulates) in conventional and organic brown rice (Oryza sativa L.). J. Cereal Sci. 2012, 55, 337-343.

98. Dolgun, O.; Ozkan, G.; Erbay, B. Comparison of olive oils derived from certified organic and conventional agricultural methods. Asian J. Chem. 2010, 22, 2339-2348.

99. Perretti, G.; Finotti, E.; Adamuccio, S.; Della Sera, R.; Montanari, L. Composition of organic and conventionally produced sunflower seed oil. J. Amer. Oil Chem. Soc. 2004, 81, 1119-1123.

100. Lombardi-Boccia, G.; Lucarini, M.; Lanzi, S.; Aguzzi, A.; Cappelloni, M. Nutrients and antioxidant molecules in yellow plums (Prunus domestica L.) from conventional and organic productions: A comparative study. J. Agr. Food Chem. 2004, 52, 90-94.

101. Carbonaro, M.; Mattera, M.; Nicoli, S.; Bergamo, P.; Cappelloni, M. Modulation of antioxidant compounds in organic vs. conventional fruits (peach, Prunus persica L., and pear, Pyrus communis L.). J. Agr. Food Chem. 2002, 50, 5458-5462.

102. Jensen, M.M.; Jorgensen, H.C. Can agricultural cultivation methods influence the healthfulness of crops for foods? J. Agr. Food Chem. 2012, 60, 6383-6390.

103. Brazinskiene, V.; Asakaviciute, R.; Miezeliene, A.; Alencikiene, G.; Ivanauskas, L.; Jakstas, V.; Viskelis, P.; Razukas, A. Effect of farming systems on yield, quality parameters and sensory properties of conventionally and organically grown potato (Solanum tuberosum L.) tubers. Food Chem. 2014, 145, 903-909.

104. Gyore-Kis, G.; Deak, K.; Lugasi, A.; Csur-Varga, A.; Helyes, L. Comparison of conventional and organic tomato yield from a three-year-term experiment. Acta Alimen. 2013, 41, 486-493.

105. Zuchowski, J.; Jonczyk, K.; Pecio, L.; Oleszek, W. Phenolic acid concentrations in organically and conventionally cultivated spring and winter wheat. J. Sci. Food Agr. 2011, 91, 1089-1095.

106. Zuchowski, J.; Kapusta, I.; Szajwaj, B.; Jonczyk, K.; Oleszek, W. Phenolic acid content of organic and conventionally grown winter wheat. Cereal Res. Commun. 2009, 37, 189-197. 
107. Asami, D.K.; Hong, Y.J.; Barrett, D.M.; Mitchell, A.E. Comparison of the total phenolic and ascorbic acid content of freeze-dried and air-dried marionberry, strawberry, and corn grown using conventional, organic, and sustainable agricultural practices. J. Agr. Food Chem. 2003, 51, $1237-1241$.

108. Dimberg, L.H.; Gissen, C.; Nilsson, J. Phenolic compounds in oat grains (Avena sativa L.) grown in conventional and organic systems. Ambio 2005, 34, 331-337.

109. Crecente-Campo, J; Nunes-Damaceno, M.; Romero-Rodriguez, M.A.; Vazquez-Oderiz, M.L. Color, anthocyanin pigment, ascorbic acid and total phenolic compound determination in organic vs. conventional strawberries (Fragaria $\times$ ananassa Duch, cv Selva). J. Food Comp. Anal. 2012, $28,23-30$.

110. You, Q.; Wang, B.W.; Chen, F.; Huang, Z.L; Wang, X.; Luo, P.G. Comparison of anthocyanins and phenolics in organically and conventionally grown blueberries in selected cultivars. Food Chem. 2011, 125, 201-208.

111. Mikulic-Petkovsek, M.; Slatnar, A.; Stampar, F.; Veberic, R. The influence of organic/integrated production on the content of phenolic compounds in apple leaves and fruits in four different varieties over a 2-year period. J. Sci. Food Agr. 2010, 90, 2366-2378.

112. Zhao, X.; Nichols, J.R.; Williams, K.A.; Wang, W.Q.; Carey, E.E. Comparison of phenolic acids in organically and conventionally grown pac choi (Brassica rapa L. chinensis). J. Sci. Food Agr. 2009, 89, 940-946.

113. Wang, S.Y.; Chen, C.T.; Sciarappa, W.; Wang, C.Y.; Camp, M.J. Fruit quality, antioxidant capacity, and flavonoid content of organically and conventionally grown blueberries. J. Agr. Food Chem. 2008, 56, 5788-5794.

114. Amodio, M.L.; Colelli, G.; Hasey, J.K.; Kader, A.A. A comparative study of composition and postharvest performance of organically and conventionally grown kiwifruits. J. Sci. Food Agr. 2007, 87, 1228-1236.

115. Chassy, A.W.; Bui, L.; Renaud, E.N.C.; van Horn, M.; Mitchell, A.E. Three-year comparison of the content of antioxidant microconstituents and several quality characteristics in organic and conventionally managed tomatoes and bell peppers. J. Agr. Food Chem. 2006, 54, 8244-8252.

116. Woydylo, A.; Oszmianski, J.; Milczarek, M.; Wietrzyk, J. Phenolic profile, antioxidant and antiproliferative activity of black and red currants (Ribes spp.) from organic and conventional cultivation. Int. J. Food Sci. Technol. 2013, 48, 715-726.

117. Kazimierczak, R.; Hallmann, E.; Brodzka, A.; Rembialkowska, E. A comparison of the polyphenol and vitamin $\mathrm{C}$ content in jams of several varieties of black currants Ribes. nigrum L. from the organic and conventional cultivations. J. Res. Appl. Agr. Eng. 2009, 54, 123-129.

118. Arbos, K.A.; de Freitas, R.J.S.; Stertz, S.C.; Dornas, M.F. Antioxidant activity and phenolic content in organic and conventional vegetables. Cienc. Tecnol. Aliment. 2010, 30, 501-506.

119. Young, J.E.; Zhao, X.; Carey, E.E.; Welti, R.; Yang, S.S.; Wang, W.Q. Phytochemical phenolics in organically grown vegetables. Mol. Nutr. Food Res. 2005, 49, 1136-1142.

120. Reganold, J.P.; Andrews, P.K.; Reeve, J.R.; Carpenter-Boggs, L.; Schadt, C.W.; Alldredge, J.R.; Ross, C.F.; Davies, N.M.; Zhou, J. Fruit and soil quality of organic and conventional strawberry agroecosystems. PLoS One 2010, 5, doi:10.1371/journal.pone.0012346. 
121. Brandt, K.; Leifert, C.; Sanderson, R.; Seal, C.J. Agroecosystem management and nutritional quality of plant foods: The case of organic fruits and vegetables. Crit. Rev. Plant. Sci. 2011, 30, 177-197.

122. Nationale berichterstattung Pflanzenschutzmittel rückstände in Lebensmitteln. Bundesamt für Verbraucherschutz und Lebensmittelsicherheit. Available online: http://www.bvl.bund.de (accessed on 23 January 2014).

123. Howard. V.; Newby, J. Environmental influences in cancer aetiology. J. Nutr. Env. Med. 2006, 1-59.

124. Landau-Ossondo, M.; Rabia, N.; Jos-Pelage, J.; Marquet, L.M.; Isidore, Y.; Saint-Aimé, C.; Martin, M.; Irigaray, P.; Belpomme, D. Why pesticides could be a common cause of prostate and breast cancers in the French Carribbean Island, Martinique. An overview on key mechanisms of pesticide-Induced cancer. Biomed. Pharmacother. 2009, 63, 383-395

125. Ryan, S.D.; Dolatabadi, N.; Chan, S.F.; Zhang, X.F.; Akhtar, M.W. ; Parker, J.; Soldner, F.; Sunico, C.R.; Nagar, S.; Talantova, M.; Lee, B.; Lopez, K.; Nutter, A.; Shan, B.; Molokanova, E.; Zhang, Y.Y.; Han, X.M.; Nakamura, T.; Masliah, E.; Yates, J.R.; Nakaniski, N.; Andreyev, A.Y.; Okamoto, S.; Jaenisch, R.; Ambasudhan, R.; Lipton, S.A. Isogenic human iPSC Parkinson's model shows nitrosative stress-induced dysfunction in MEF2-PGC1 alpha transcription. Cell 2013, 155, 1652-1653.

126. McKinlay, R.; Plant, J.A.; Bell, J.N.B.; Voulvoulis, N. Endocrine disrupting pesticides: Implications for risk assessment. Environ. Int. 2008, 34, 168-183.

127. Mnif, W.; Hassine, A.I.H.; Bouaziz, A.; Bertegi, A.; Thomas, O.; Roig, B. Effect of endocrine disruptor pesticides: A review. Int. J. Environ. Res. Public Health. 2011, 8, 2265-2303.

128. Lu, C.; Toepel, K.; Irish, R.; Fenske, R.A.; Barr, D.B.; Bravo, R. Organic diets significantly lower children's dietary exposure to organophosphorous pesticides. Environ. Health Perspect. 2006, 114, 260-263.

129. Lu, C.; Knutson, D.E.; Fisker-Andersen, J.; Fenske, R.A.; Biological monitoring survey of organophosphorus pesticide exposure among preschool children in the Seattle Metropolitan area. Environ. Health Perspect. 2001, 109, 299-303.

130. Magkos, F.; Arvaniti, F.; Organic food: Buing more safety or just peace in mind? A critical review of the literature. Crit. Rev. Food Sci. Nutr. 2006, 46, 23-56.

131. Zaccone, C.; di Caterina, R.; Rotunno, T.; Quinto, M. Soil-farming system-Food-Health: Effect of conventional and organic fertilizers on heavy metal $(\mathrm{Cd}, \mathrm{Cr}, \mathrm{Cu}, \mathrm{Ni}, \mathrm{Pb}, \mathrm{Zn})$ content in semolina samples. Soil Till. Res. 2010, 107, 97-105.

132. Mansour, S.A.; Belal, M.H.; Abou-Arab, A.A.K.; Gad, M.F. Monitoring of pesticides and heavy metals in cucumber fruits produced from different farming systems. Chemosphere 2009, 75, 601-609.

133. Mansour, S.A.; Belal, M.H.; Abou-Arab, A.A.K.; Ashour, H.M.; Gad, M.F. Evaluation of some pollutant levels in conventionally and organically farmed potato tubers and their risks to human health. Food Chem. Toxicol. 2009, 47, 615-624.

134. Rossi, F.; Bertuzzi, T.; Comizzoli, S.; Turconi, G.; Roggi, C.; Pagani, M.; Cravedi, P.; Pietri, A. Preliminary survey on composition and quality of conventional and organic wheat. Ital. J. Food Sci. 2006, 18, 355-366. 
135. Muchova, Z.; Jaska, P. The influence of growing conditions on the cadmium and lead accumulation in food wheat. Rostl. Vyroba 1996, 42, 59-62.

136. Domagala-Swiatkiewicz, I.; Gastol, M. Comparative study on mineral content of organic and conventional carrot, celery and red beet juices. Acta Scientiarum Polonorum-Hortorum Cultus 2012, $11,173-183$.

137. Vrcek, V.; Vrcek, I.V. Metals in organic and conventional wheat flours determined by an optimized and validated ICP-MS method. Int. J. Food Sci. Technol. 2012, 47, 1777-1783.

138. Rossi, F.; Godani, F.; Bertuzzi, T.; Trevisan, M.; Ferrari, F.; Gatti, S. Health-promoting substances and heavy metal content in tomatoes grown with different farming techniques. Eur. J. Nutr. 2008, 47, 266-272.

139. Dos Santos, J.S.; dos Santos, M.L.P.; Contil, M.M. Comparative study of metal contents in Brazilian coffees cultivated by conventional and organic agriculture applying principal component analysis. J. Braz. Chem. Soc. 2010, 21, 1468-1476.

140. Hussain. A.; Larsson H.; Kuktaite, R.; Johansson, E. Concentration of some heavy metals in organically grown primitive, old and modern wheat genotypes: Implications for human health. J. Environ. Sci. Health Part. B 2012, 47, 751-758.

141. Velimirov, A.; Huber, M.; Lauridsen, C.; Rembialkowska, E.; Seidel, K.; Bügel, S. Feeding trials in organic food quality and health research. J. Sci. Food Agr.2010, 90, 175-182.

142. Paci, G.; Lisi, E.; Bagliacca, M.; Maritan, A. Reproductive performance in a local rabbit population reared under organiconventional system (Tuscany). Ann. Facolta Med. Veterinria Pisa 2003, 56. Available online: http://eprints.adm.unipi.it/142/1/115.pdf (accessed on 3 April 2014).

143. Huber, M.; de Vijver, L.P.L.V.; Parmentier, H.; Savelkoul, H.; Coulier, L.; Wopereis, S.; Verheij, E.; van der Greef, J.; Nierop, D.; Hoogenboom, R.A.P. Effects of organically andconventionally produced feed on biomarkers of health in a chicken model. Brit. J. Nutr. 2010, 103, 663-676.

144. Finamore, A.; Britti, M.S.; Roselli, M.; Bellovino, D.; Gaetani, S.; Mengheri, E. Novel approach for food safety evaluation. Results of a pilot experiment to evaluate organic and conventional foods. J. Agr. Food Chem. 2004, 52, 7425-7431.

145. Lauridsen, C.; Young, C.; Halekoh, U.; Bügel, S.H.; Brandt, K.; Christensen, L.P.; Jorgensen, H. Rats show differences in some biomarkers of health when eating diets based on ingredients produced with three different cultivation strategies. J. Sci. Food Agr. 2008, 88, 720-732.

146. Baranska, A.; Skwarlo-Sonta, K.; Rembialkowska, E.; Brandt, K.; Lueck, L.; Leifert, C. The Effect of Short Term Feeding with Organic and Conventional Diets on Selected Immune Parameters in Rat. In Improving Sustainability in Organic and Low Input Food Production Systems; Niggli, A., Leifert, C., Alfoldi, C., Luck, L., Willer, H., Eds.; University of Hohenheim: Stuttgart, Germany, 2007; pp. 108-111.

147. Roselli, M.; Finamore, A.; Brasili, E.; Capuani, G.; Kristensen, H.L.; Micheloni, C.; Mengheri, E. Impact of organic and conventional carrots on intestinal and peripheral immunity. J. Sci. Food Agric. 2012, 92, 2913-2922.

148. Chhabra, R.; Kolli, S.; Bauer, J.H. Organically grown food provides health benefits to Drosophila melanogaster. PLoS One 2013, 8, doi:10.1371/journal.pone0052988.

149. Plochberger, K. Feeding experiments - A criterion for quality estimation of biologically and conventionally produced foods. Agr. Ecosyst. Environ. 1989, 27, 1-4. 
150. Magkos, F.; Arvaniti, F.; Zampelas, A. Organic food: Nutritious food or food for thought? A review of the evidence. Int. J. Food Sci. Nutr. 2003, 54, 357-371.

151. Rembialkowska, E.; Kazimierczak, R.; Srednicka, D.; Bienko, K.; Bielska, M. Different aspects of organic and conventional food consumers' lifestyle. New Med. 2008, 12, 16-19.

152. Kesse-Guyot, E.; Péneau, S.; Méjean, C.; de Edelenyi, F.S.; Galan, P.; Hercberg, S.; Lairon, D. Profiles of organic food consumers in a large sample of French adults: Results from the nutrinet-sante cohort study. PLoS One 2013, 8, doi:10.1371/journal.pone0076998.

153. Akcay, Y.D.; Yildirim, H.K.; Guvenac, U.; Sozmen, E.Y. The effects of consumption of organic and nonorganic red wine on low-density lipoprotein oxidation and antioxidant capacity in humans. Nutr. Res. 2004, 24, 541-554.

154. Briviba, K.; Stracke, B.A.; Rufer, C.E.; Watzl, B.; Weibel, F.P.; Bub, A. Effect of consumption of organically and conventionally produced apples on antioxidant activity and DNA damage in humans. J. Agr. Food Chem. 2007, 55, 7716-7721.

155. Stracke, B.A.; Ruefer, C.E.; Bub, A.; Briviba, K.; Seifert, S.; Kunz, C.; Watzl, B. Bioavailability and nutritional effects of carotenoids from organically and conventionally produced carrots in health men. Brit. J. Nutr. 2009, 101, 1664-1672.

156. Stracke, B.A.; Ruefer, C.E.; Weibel, F.P.; Bub, A.; Watzl, B. Three-year comparison of the polyphenol contents and antioxidant capacities in organically and conventionally produced apples (Malus domestica Bork. Cultivar "Golden Delicious". J. Agr. Chem. 2009, 57, 4598-4605.

157. Grinder-Pedersen, L.; Rasmussen, S.E.; Bugel, S.; Jorgensen, L.V.; Dragsted, L.O.; Gundersen, V.; Sandstrom, B. Effect of diets based on foods from conventional vs. organic production on intake and excretion of flavonoids and markers of antioxidative defense in humans. J. Agr. Food Chem. 2003, 51, 5671-5676.

158. Kummeling, I.; Thijs, C.; Huber, M.; van de Vijver, L.P.L.; Snijders, B.E.P.; Penders, J.; Stelma, F.; van Ree, R.; van den Brandt, P.A.; Dagnelie, P.C. Consumption of organic foods and risk of atopic disease during the first 2 years of life in the Netherlands. Brit. J. Nutr. 2008, 99, 598-605.

159. Alfven, T.; Braun-Fahrlander, C.; Brunekreef, B.; von Mutius, E.; Riedler, J.; Scheynius,A.; van Hage, M.; Wickman, M.; Benz, M.R.; Budde, J. Allergic diseases and atopic sensitization in children related to farming and anthroposophic lifestyle-The PARSIFAL study. Allergy 2006, $61,414-421$.

160 Organic, More Healthy? A Search for Biomarkers of Potential Health Effects Induced by Organic Products, Investigated in a Chicken Model, 2nd ed.; Huber, M., Ed.; Louis Bolk Instituut: Driebergen, The Netherlands, 2007.

161. Paynter, N.P.; Everett, B.M.; Cook, N.R. Cardiovascular disease risk prediction in women: Is there a role for novel biomarkers? Clin. Chem. 2014, 60, 88-97.

162. Weigelt, B.; Bissell, M.J. The need for complex 3D culture models to unravel novel pathways and identify accurate biomarkers in breast cancer. Adv. Drug Delivery Rev. 2014, doi:10.1016/j.addr.2014.01.001.

163. Olsson, M.E.; Gustavsson, K.E.; Andersson, S.; Nilsson, A.; Duan, R.D. Inhibition of cancer cell proliferation in vitro by fruit and berry extracts and correlations with antioxidant levels. J. Agr. Food Chem. 2004, 52, 7264-7271. 
164. Stoner, G.D.; Wang, L.S.; Casto, B.C. Laboratory and clinical studies on cancer chemoention by antioxidants in berries. Carcinogenesis 2008, 29, 1655-1674.

165. Olsson, M.E.; Andersson, C.S.; Oredsson, S.; Berglund, R.H.; Gustavsson, K.E. Antioxidant levels and inhibition of cancer cell prolifieration in vitro by extracts from organically and conventionally cultivated strawberries. J. Agr. Food Chem. 2006, 54, 1248-1255.

166. Wang, S.A.; Meckling, K.A.; Marcone, M.F.; Kakuda, Y.; Tsao, R. Can phytochemical antioxidant rich foods act as anti-cancer agents? Food Res. Int. 2011, 44, 2545-2554.

167. Brown, E.M.; Gill, C.I.R.; McDougall, G.J.; Stewart, D. Mechanisms underlying the anti-proliferative effects of berry components in in vitro models of colon cancer. Curr. Pharm. Biotechnol. 2012, 13, 200-209.

(C) 2014 by the authors; licensee MDPI, Basel, Switzerland. This article is an open access article distributed under the terms and conditions of the Creative Commons Attribution license (http://creativecommons.org/licenses/by/3.0/). 